\title{
Valuing Fishing Activity of the Deepor Beel
}

\author{
Jyotisikha Dutta $^{+*}$ and Archana Sharma*
}

\section{Abstract}

The Deepor Beel is one of the large and important riverine wetlands in the Brahmaputra valley of Assam, India. The only Ramsar site of Assam, the Beel is one of the richest biodiversity grounds in the wetland eco-system of the state. The Deepor Beel is the hub of a wide range of organisms. It provides various goods and services directly or indirectly to the villages near to the beel for their livelihood. Despite its contribution to society and ecology as a whole, these goods and services of the Beel are undervalued in the policy provisions. The prime reason for this undervaluation is that most of the goods and services of the Beel are non-marketable and those goods which have direct use-values are never valued in an economic term. To fill the gap partially, this study tries to estimate the direct use values of the Deepor Beel. Among the goods the Deepor Beel provides, fishing can be considered one of the economically significant goods. Fishing provides livelihood directly to 825 households living near the Beel. Therefore, this research tries to estimate the direct use value of fishing in the Deepor Beel. A market price approach is applied to estimate the value of this wetland resource. Net Present Value (NPV) of fishing is also estimated. The total estimated value of fishing is INR $11,64,69,375$ per annum. The estimated value of fishing per hectare is INR 29,015.78 per annum. The estimated Net Present Value (NPV) of fishing is INR 97,05,78,125. This valuation is important to draw the attention of the policymakers for resource investment in conserving the Beel for continued benefits.

Keywords: Direct Use Value; Economic Valuation; Market Price Approach; Net Present Value (NPV); Deepor Beel; Assam; India

\footnotetext{
' Senior Laboratory Assistant, Department of Women's Studies, Gauhati University

${ }^{*}$ Corresponding Author, Email: jyotisikhadatta@gauhati.ac.in

¥ Professor and Former Head, Department of Economics; Formerly Director, Women's Studies Research Centre and founder Head, Department of Women's Studies, Gauhati University, Guwahati-781014, Email: archasharma@gmail.com

(C) 2020 Dutta \& Sharma. This is an Open Access article distributed under the terms of the Creative Commons Attribution License (http://creativecommons.org/licenses/by/2.0), which permits unrestricted use, distribution, and reproduction in any medium, provided the original work is properly cited.
} 


\section{Introduction}

Wetlands, on the one hand, are the most productive ecosystem providing various significant services to human and wildlife and on the other, these are the ecologically sensitive systems (Gokce, 2018). A single wetland system can provide multiple ecosystem services such as provisioning, regulating, cultural and suppoting service (Sofia \& Nurlianti, 2019). The ecosystem services of wetlands are mostly undervalued by society, resulting in the conversion of the wetlands. The wetlands in India are also facing the acute problem of existence. Even though many conservation and protection acts are enacted, the rate of loss of wetland is increasing at a fast pace. Studies depict that India has lost more than 38 per cent of its wetlands in the last decade. In some districts, the rate has been as high as 88 per cent (Vijayan et al., 2004). The principal causes of degradation are habitat destruction by land-filling, hydrological alterations, upstream dams and pollution by industrial and domestic sources.

Assam in the northeast part of India has also been experiencing the fast conversion or loss of wetlands since the 1990s (Deka et al., 2011). The only Ramsar site ${ }^{1}$ of Assam, the state of the Deepor Beel ${ }^{2}$ is of no difference. The Deepor Beel (Figure 1) was declared as the Ramsar site in November 2002. The Deepor Beel is one of the important natural freshwater wetlands of Assam. According to the information available in Ramsar website, the Beel is situated within the coordination of $26^{\circ} 08^{\prime} \mathrm{N} 091^{\circ} 39^{\prime} \mathrm{E}$. The Beel lies on the southwestern fringe of Guwahati City (Saikia 2005). The main sources of water to the Beel are Basistha river, Kalmani river and local monsoon run-off. Through Khonajan channel, the beel drains its water into the Brahmaputra River. The Deepor Beel acts as a natural storm water reservoir for the Guwahati city during the monsoon season. It is a hub of varied wild flora and fauna. Several endemic, endangered and threatened animals, birds and plants are found in the Deepor Beel (Saikia \& Bhattacharjee, 1987; Saikia, 2005; Saikia \& Saikia, 2011). Some of the flora and fauna are included in the Directory of Asian Wetlands (IUCN, 1987). The Beel is the breeding ground of many rare fish species. The Deepor Beel is under tremendous pressure due to development activities and unsustainable land-use practices. Unlawful encroachment, discharge of pollutants, air pollution created by the brick kilns set up in the Beel area, construction of road and railway lines on the Beel area are major factors responsible for the degradation of this ecosystem. Siltation, dumping of solid waste materials and toxic chemical discharge by the inlet channels to the wetland have reduced its carrying capacity significantly leading to a rapid depletion of its fish productivity. As a result, many fishermen families have lost their livelihoods. Due to these anthropogenic pressure, the area of this wetland has been diminishing over the years. A study conducted by Deka et al. (2011) on the monitoring of changes in the spatial extent of the Deepor Beel found that the total area of open water bodies has diminished $2.904 \mathrm{sq}$. Km from 1991 to 2010. Meng \& Dong (2019) has also undertaken a similar study on Nansi lake in China which shows that over 30 years (19872017), $54.4 \%$ of the natural wetlands in Nansi Lake were replaced by constructed wetlands.

Various programs and policies were introduced by the Government of Assam to protect this inimitable wetland. The government declared it as a wildlife sanctuary in 1989 under the Wildlife Protection Act, 1972 (Forest Reports, Govt. of Assam, 1992). The wetland was included in Birdlife International lists as an Important Bird Area in 2004 (Islam \& Rahmani, 2004). In 2008, 4.14 sq. $\mathrm{km}$ of the Beel was declared as Bird Sanctuary. In the same year, the Guwahati

\footnotetext{
${ }^{1} \mathrm{~A}$ Ramsar site is a wetland site chosen as a site of international importance under the Ramsar Convention. The key aim of the Ramsar Convention is to protect and conserve the world's wetland. Therefore, an intergovernmental environmental treaty was established in 1971 at Ramsar, Iran through a convention. This convention is known as the Ramsar Convention.

${ }^{2}$ Beel means lake in the Assamese language.
} 
Water Bodies (Preservation and Conservation) Act, 2008 was introduced. The Act was meant to conserve and preserve the water bodies that come under the jurisdiction of the Guwahati Metropolitan Development Authority (GMDA). The Act prohibits certain activities in the waterbodies such as dumping of solid waste, developmental activities, encroachment which may reduce the size of the water-bodies (Saikia, 2019). Surprisingly, Guwahati Municipal Corporation (GMC) took the devastating decision of transferring the landfill area of the Guwahati city to the Deepor Beel in year the
2008 itself. No significant action in real sense is taken up till now to stop waste dumping, encroachment or other illegal activities on the Beel. The key reason for above mentioned scenario is the misunderstanding of the policymakers regarding the real value of the Deepor Beel. Like other natural resources, the ground of the undervaluation of the Deepor Beel is that most of the goods and services of the Beel are non-marketable and those goods which have direct use value are never valued in an economic term.

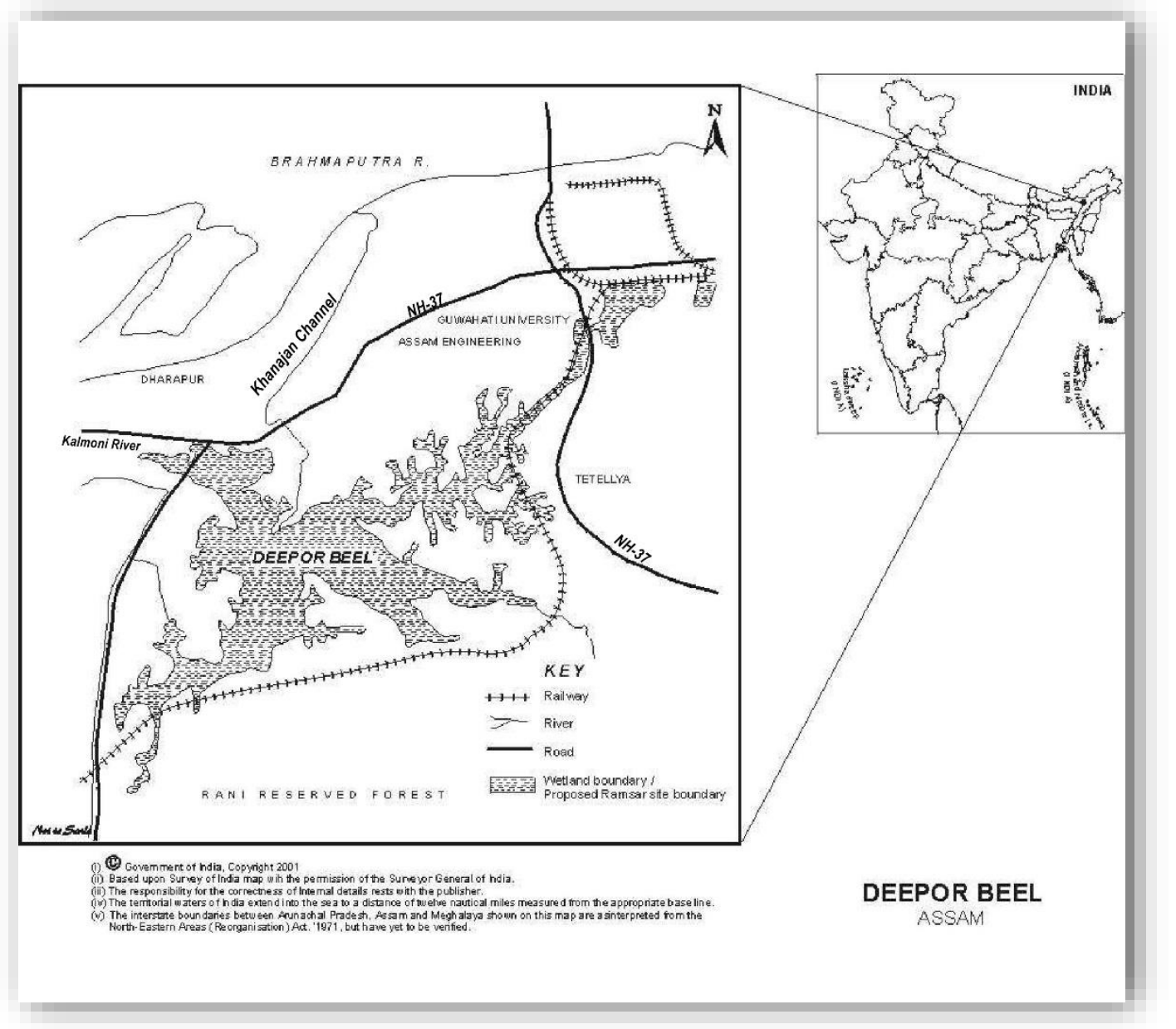

Figure 1: Map of Deepor Beel

Source: Ramsar website. Retrieved on 31 December 2019 from, https://rsis.ramsar.org/RISapp/files/41543220/pictures/IN1207map.pdf

Although extensive studies on hydrological, physical, chemical, ecological functions of the Deepor Beel have been conducted, no study on economic valuation of goods and services of the Beel was conducted till 2012. The attempt was taken up by the author (Dutta, 2017) to conduct an economic valuation of the Deepor Beel as her doctoral research. As a part of her research work she presented a paper on the socio-economic value of the Deepor Beel in 2012 in an international seminar held in Nepal (Dutta and Sharma, 2012) where she carried out valuation of both use and non-use values of the Beel. This 
study is based on the doctoral research work of the first author.

The values of goods and services provided by the Beel to the human and other living things come under use and non-use values. Under use-values, the Beel provides a few numbers of goods which has direct use-values. Among them, fishing can be considered as the economically significant good as most of the people, directly and indirectly depend on fishing as their source of livelihood and source of nutrients. This observation has also been reinforced by Pandit et al. (2018) who argue about the development of aqua-tourism in Deepor Beel as they found fishery is the major occupation of the fishermen residing near the Deepor Beel area. Seemingly, in a slightly different spatial context of North Hulu, Sungai Regency, South Kalimantan, Indonesia, Sofia \& Nurlianti (2019) argue that traditional fishing plays an important role as a source of livelihood for most households in wetland areas. Fishing is considered both as a source of household protein as well as money.

Considering the importance of fishing, this research paper tries to estimate the direct use value of fishing in the Deepor Beel. The structure of the study is as follows: in the next section, the key methods adopted in the study has been discussed. Following this, it discusses the result of the study. The conclusion of the study has been summarised in the final section.

\section{Research Methodology}

\section{Sources of Data}

Both primary and secondary data sources are used in the study. Secondary information is collected from the reports available in Ramsar website; reports retrieved from the Ministry of Environment and Forest (MoEF), Government of India on Indian Wetlands, and MoEF sponsored reports prepared by ARSAC, ${ }^{3}$ ASTEC. ${ }^{4}$ Different reports and publications of individual researchers are also consulted to construct the backdrop of the study. Primary sources of data

\footnotetext{
${ }^{3}$ Assam Remote Sensing and Application Centre

${ }^{4}$ Assam Science Technology and Environment Council
}

have been collected through a household survey.

\section{Sampling Design and Sample Size}

According to the Resource Inventory of Beel Fishery, 2015, 825 households, living in the villages adjacent to the Beel, directly depend on fishing as their source of livelihood. This study deployed stratified random sampling procedure. For this, first, the villages are divided into different strata according to the residents who are involved in fishing. The random sampling procedure is then followed to select sample households to conduct the survey. From the 825 fishing households, 20 per cent of the households are taken as samples. A structured information schedule survey is conducted among 165 households. A brief description of the scope and coverage of the study and possible outcomes are explained at the beginning of the interview. To collect the required data, a doorto-door survey was carried out. Apart from the household survey, other necessary information were collected from the Village Headman. The survey was conducted from January to February 2016.

\section{Analytical Method for Calculating the Value of Fishing}

The calculation of economic value crucially depends on the selection of appropriate tools. In this study, the market price approach is used to estimate the gross and net value of fishing activity in the Beel area. The market price approach uses the prices of goods and services of an ecosystem as a tool to determine the value of an ecosystem service which is bought and sold in commercial markets (Carson \& Bergstrom, 2003). As it is believed that the market provides precise information about the value of goods and services, therefore, the private and social willingness to pay for the traded ecosystem services is reflected in the market operation.

The use of the market price approach can be seen in the study conducted by Das et al. (2000) to calculate the economic value of ten wetlands

\footnotetext{
${ }^{5}$ Resource Inventory of Beel Fishery, 2010 is prepared by the Village Headmen to submit to the respective Revenue Circle Office.
} 
in the Gangetic flood plain in Bardhaman district of West Bengal. The value of the fisheries in operation in these wetlands varies from INR 500 to INR. 16,000 per ha per year. Verma (2001) estimated the economic value of Bhoj wetland. In the study, she estimated the annual total earnings of fishing as INR 80,00,000 with the help of the market valuation method. The same analytical tool is also used by Roy et al. (2012) to estimate the annual (average) income of fishing of Bhomra Beel in their study on socio-economic valuations of wetland based occupations of Lower Gangetic Basin. The estimated value of this study stood at INR 1200. Meng \& Dong (2019) also used Market value approach (MV) to value fishing in Nansi lake, China and the result

$$
\begin{aligned}
& N F=V_{i}-C_{i} \\
& \text { where, } \\
& N F=\text { Net monetary annual benefits from fish catch from the wetland } \\
& V=\text { average annual monetary value ofthe fish catch } \\
& C=\text { various cost incur during fishing } \\
& (C=n+e+b+m) \text { (average annual cost) } \\
& n=\text { cost of net used per year } \\
& e=\text { cost of equipment used tokeep caught fish per year } \\
& b=\text { cost of boats per year } \\
& m=\text { cost of maintenance of boats per year } \\
& i=\text { individual household }
\end{aligned}
$$

unravelled that in the local market, the average price of fish was $\$ 1.745 \times 103 / \mathrm{t}$. The average unit area yield were $31.5 \mathrm{t} / \mathrm{sq}$. $\mathrm{Km}$ in natural water and $225 \mathrm{t} / \mathrm{sq}$. $\mathrm{Km}$ in aquaculture area. Seemingly, Kauffman (2018) too found that the residents of Delaware, US spent an estimated $\$ 62$ million on fishing. He tried to quantify the economic value of Delware wetlands. The Net Present Value (NPV) of the Delware wetlands has also been measured over 100 years. nenefit from commercial fishing per household is estimated with the help of the following expression:
The total net money value of fishing is calculated by multiplying net monetary benefits per household to the total population of fishers.

To make the results more precise, the input value of food production should be considered. Fish in natural water mainly feed on plankton, therefore, the input value can be neglected (Meng \& Dong, 2019). The following section estimates the current net value of fishing in the study area.

\section{Results}

\section{Estimation of Present Net Value of Fishing}

It can be considered that goods and services provided by the Deepor Beel have a substantial share in the economy of the Guwahati City. If we think of the goods \& services provided by the Deepor Beel as a stream of annual 'income', then the Beel can be considered as part of Guwahati city's total natural capital. This observation is similar to the argument made by Bateman et al., (2011). Net Present Value (NPV) is used to convert the stream of benefits from the future flows of ecosystem services to figure out the value of this natural resource capital. Net Present Value (NPV) is an economic term representing the economic value of a natural resource item over time, discounted to presentday terms (Azar and Sterner, 1996). The Wetland benefits are often expressed as a yearly flow of money. If this yearly flow is expected to continue indefinitely, there is an easy formula for the relationship between NPV and yearly flow: NPV = yearly flow of net income/discount rate (Liu et. al., 2010). Here, NPV is calculated for fishing activity. The results of the fishing activities of the study area are outlined in the following sections. 


\section{Identification of Major Goods Provided by the Deepor Beel to the Resource Users}

As stated above, an in-depth survey was conducted to identify the economic activities performed in and around the Deepor Beel area. It is found in the survey that fishing, paddy cultivation, and fodder collection are the major activities that are carried out by the local residents dwelling in and around the Beel area. A significant number of local people who belong to the fishing community depend on the Beel. Fishing is the main source of livelihood of these people. A total of 825 families depend directly on fishing. The fish is also the main source of protein of these people.

\begin{tabular}{|l|l|}
\hline \multicolumn{2}{|l|}{ Table 1: Information on Time Spent on Fishing Per Day in the Beel } \\
\hline \begin{tabular}{l} 
Information \\
\hline Number of People that Go for Fishing per Day
\end{tabular} \\
\hline 1 & $10(6.06)$ \\
\hline 2 & $125(75.75)$ \\
\hline 3 & $30(18.19)$ \\
\hline No of days fish in a week & $30(18.18)$ \\
\hline 6 or less & $135(81.82)$ \\
\hline 7 & \\
\hline $\begin{array}{l}\text { Numbers in Brackets Indicate Percentage to the Total } \\
\text { Source: Survey Data }\end{array}$
\end{tabular}

\section{Time Spent on Fishing}

Results of the survey indicate that households mostly fish along the periphery of the Beel. Only on the occasion of Magh Bihu and Bohag Bihu (one of the major festivals of Assam), people fish near the core area of the wetland. Most of the households (81.82 per cent) fish for 7 days a week; only 18.18 per cent of the households fish for 6 or fewer days a week. On average, a household spends approximately three and a half hours in the morning and three and a half hours in the evening per day for fishing in the Beel. From every household, on average two members go for fishing everyday (see Table 1).

\section{Various Tools Used During Fishing}

The fishermen use different nets to catch various sizes of fishes. They also use jakoi or khawoi.
The nets are made of different small parts such as sola, goli, bai, etc. Generally, women are engaged in making or weaving fishing nets. Approximately, four to five hours is required to complete the weaving of a net. The detail of various nets used during fishing in the Beel are given below in Table 2 . Usually, people do not collect other vertebrate and invertebrate from the Beel other than fish. In the case of plants, sometimes people collect water lily or mokuwa for eating. There is no storage facility for the caught fish. This is the reason that fishermen do not go for overfishing. Overfishing leads to wastage of caught fish which will lead to a reduction of fish stock in the Beel, indirectly hamper their source of livelihood in long run.

Table 2: Information on Various Nets Used During Fishing

\begin{tabular}{|l|l|c|l|}
\hline Type & Nets & Size & Fish size \\
\hline Small & $\begin{array}{l}\text { Parangi, ghoka, sana langi, } \\
\text { kawai langi }\end{array}$ & $10 \mathrm{~mm}-15 \mathrm{~mm}$ & Small \\
\hline Middle & $\begin{array}{l}\text { Puthi langi } \\
\text { Lange } \\
\text { jaal, } \text { polo, bareng/ faasi, Basu }\end{array}$ & $\mathbf{2 5 \mathrm { mm } - 3 5 \mathrm { mm }}$ & Medium \\
\hline Source: Survey Data & $70 \mathrm{~mm}-200 \mathrm{~mm}$ & Large \\
\hline
\end{tabular}

\footnotetext{
${ }^{6}$ Polo, barasi: local name of fishing equipments which are also used for fishing other than nets.
} 


\section{The Monetary Value of the Fish Catch}

The small-sized fishes are generally caught during the winter season. Big sized fishes are caught in summer season along with small-sized fishes. Fishing is comparatively reduced during summer due to the increase in the water level of the Beel. Fishermen generally sell fishes they catch to the fish sellers at per Aska. ${ }^{7}$ One Aska is equivalent to $4-5 \mathrm{kgs}$ of fish. From the sample it has found that the value of each Aska ranges from INR 400 to INR 500 depending on the variety of fishes they catch. Some fishermen also sell their caught fish to the local market. They sell their fish at per bhag. ${ }^{8}$ Each bhag cost around INR 20 to INR 30. The percentage of those people is negligible. Therefore, the bigger unit of measurement is considered for the calculation. The calculation of the money value of fishing is considered by the average income earned by a fisherman (see Table 3).

\begin{tabular}{l|l|}
\hline Table 3: Monetary Value of Fishing & \multicolumn{1}{c}{ Amount } \\
\hline Variables & INR 450 (400 to 500) \\
\hline Average Income earn by each day per Aska & INR 13,500 \\
\hline The average income per month & INR 1,62,000 \\
\hline &
\end{tabular}

\section{The Cost Incurred in Fishing}

Every household poses a boat for fishing. The boats are made of wood. One boat costs around INR 25,000 to INR 35,000 . One boat last for four years. The fishermen do not use boats run by the engine as they believe that the sound of the engine may hamper the environment of the Beel affecting the fish stock in the Beel. Another reason which keeps the fishermen away from using an engine in the boats is that the engine creates vibration in water due to which fishes try to run away from the route where the boats pass. This generally disturbs the fishermen to catch fish. To use the boats for a long period, fishermen have to maintain their boats. They use coal $\operatorname{tar}^{9}$ in the whole body of the boats so that they cannot be damaged by the polluted water of the Beel. The cost of the maintenance of the boats is approximately INR 300 per year.

Various types of nets are used in fishing. The costs of raw materials used to make a net; the cost of equipment such as khara (to keep the caught fish) are included in the estimation of the cost incurred in fishing. The details of the various costs incurred in fishing are presented below (see Table 4).

\footnotetext{
${ }^{7}$. Aska is the unit of measurement for fish used by the local fishermen of Deepor Beel. The measurement is bigger than bagh.

${ }^{8}$ Smallest unit of measurement for fishing. 1 bhag contains $20-25$ fishes
} 


\begin{tabular}{l|l|}
\hline \multicolumn{2}{|l|}{ Table 4: Information Related to The Cost of Fishing Per Household } \\
\hline Variables & Amount \\
\hline Parts of nets and their costs & INR 150 \\
\hline Sola & INR 250 \\
\hline Goli (1kg=INR 50) needed 5 kgs & INR 550 \\
\hline Jaal (average) & INR 200 \\
\hline Bai (1kg= INR 50) needed 4 kgs & INR 1150 \\
\hline Cost of 1 net (jaal) & \\
\hline & \\
\hline Nets needed in a year & $2+2+2+2$ \\
\hline For small fish (puthi langi, kawai langi, baro and kareng net) & 2 \\
\hline For medium fish (parangi langi net) & 1 (total 11 nets) \\
\hline For large fish(langar langi net) & INR 12650 \\
\hline The total cost of 11 nets & (INR 1150 X11) \\
\hline Average Cost of equipment(khara) used to keep fish after been & INR 125 per khara \\
\hline caught & \\
\hline Cost of required khara(3 khara per year) & INR 375 \\
\hline Average Cost of boats for 4 years & INR 30,000 \\
\hline The average cost of boats per year & INR 7,500 \\
\hline Cost of maintenance of boats per year & INR 300 \\
\hline Total cost per year & INR 20,825 \\
\hline & \\
\hline Source: Survey data, INR: Indian Rupee & \\
\hline
\end{tabular}

Therefore, the Net Monetary Benefits from the fishing per annum is

$N F=V_{i}-C_{i}$

$=$ INR 1,62,000- INR 20,825

$=$ INR 1,41,175 per household

The total value of fishing is INR $1,41,175 \times 825=$ INR $11,64,69,375$

Value of Fish in per hectare of the Deepor Beel

The per hectare yield of fish is calculated by dividing the total value of the fishing by the total area of the Beel. The total area of the Beel is 4,014 hectares. The total value of fishing is INR $11,64,69,375$ per annum. Therefore, per hectare value per annum of fishing in the Deepor Beel is INR 29,015.78.

\section{Estimation of Net Present Value (NPV) for Fishing}

As stated above, to determine the NPV of fishing, the net annual value of fishing is divided by a discount rate. In this study, the discount rate considered is 12 per cent. This discount rate is equivalent to the interest rate of the loan of the cooperatives society of that locality. The name of the cooperative society is Bandhan which has now turned into a bank. The fishermen take loans from this cooperative society for buying boat and other necessary equipment for their livelihood.

The estimated Net Present Value (NPV) of fishing for an infinite period is INR 97,05,78,125. The finding of this study bear resonance to the study of Stuip et al. (2002), who conducted a study on 
socio-economics of wetlands. In this study they included case studies from developing countries that address different wetland types and values. In the case of Mirja Zerga wetland of Morocco, NPV for agriculture is estimated considering the infinite period. The estimated value of NPV for agriculture is 33 million US \$ at a 6 per cent discount rate.

\section{Conclusion}

The environment of the Deepor Beel is under continuous deterioration. Its real conservation has been neglected over the years. As mentioned earlier, the Government has allocated a good amount of money for the conservation, preservation and development of the Beel, yet, its ecological quality and spatial size have been degraded incessantly. Decisionmakers consider the allocated amount of money for the Beel as a cost without getting any return in monetary terms. The result of the study should be the eye-opener for them. With this ailing state, if the Deepor Beel can generate a significant amount of money (that it only for fishing), what would be the scenario if the Beel would be restored and conserved. It could be interpreted that if the Beel was conserved by increasing its ecological quality and spatial size, then it would generate more income and become a productive asset. The present results might prove very useful for decision-makers and local stakeholders, developing a management plan for the Deepor Beel.

\section{Acknowledgement}

The authors are grateful to the Gaon Burha (Village Headman) of Keotpara Mr. Sarat Das, for his help in conducting a household survey and gathering other secondary data needed for the study. The authors are also thankful to all the respondents for their cooperation and support.

\section{References}

Azar, C. and Sterner, T. (1996). Discounting and Distributional Considerations in the Context of Global Warming. Ecological Economics, 19, 169184. DOI:10.1016/0921-8009(96)00065-1

Bateman, I.J., Abson, D., Beaumont, N., Darnell, A., Fezzi, C., Hanley, N., Kontoleon, A., et al.
(2011). Chapter 22: Economic values from ecosystems. In: UK National Ecosystem Assessment: technical report, pp. 1067-1152.

Carson R. M. Bergtrom J. C. (2003). A Review of Ecosystem Valuation Techniques. Department of Agricultural and Applied Economics University of Georgia Athens, GA 30602-7509.

Das, T.K., Moitra, B., Raichaudhuri, A., Jash, T., Ghosh, S., Mukherjee, A. (2000). Degradation of Water Bodies and Wetlands in West Bengal: Interaction with Economic Development. Final Report, Funded by Environmental Economics Research Committee, World Bank Aided India: Environmental Management Capacity Building Programme

Deepor Beel, Ramsar Sites Information Service, Retrieved21 February 2020 from, https://rsis.ramsar.org/ris/1207

Deka, J., Tripathi, O. P., Khan, M. L. (2011). A multi-temporal remote sensing approach for monitoring changes in spatial extent of freshwater lake of Deepor Beel Ramsar Site, a major wetland of Assam. Journal of Wetlands Ecology, 5, 40-47.

DOI: http://dx.doi.org/10.3126/jowe.v5i0.4696

Dutta, J., Sharma, A. (2012). Socio-Economic and Conservational Value of Deepor Beel, Assam. International Wetland Symposium, 2012 (pp 125-13). Conservation and Sustainable Use of Wetland in Nepal

Dutta, J. (2017). Economic Valuation of the Deepor Beel, Assam. (Unpublished doctoral thesis). Gauhati University, Guwahati, India Forest Reports, Government of Assam, 1998 Gokce, D. (2018). Introductory chapter: Wetland Importance and Management in Wetland Management-Assessing Risk and Sustainable Solution. In Didem Gokce(Ed.). Wetlands Management - Assessing Risk and Sustainable Solutions (pp 3-10). London, UK: Intech Open Publishing.

DOI:10.5772/intechopen.82456

Islam, M.Z. Rahmani, A.R. (2004). Important Bird Areas in India. Priority Sites for Conservation. Indian Bird Conservation 
Network, Bombay Natural History Society and BirdLife International (UK).

IUCN (1987). Directory of Asian Wetlands. Published by IUCN Participating Organizations with collaboration of IUCN, IWRB, ICBP and WWF-International, Oxford University press, Oxford.

Liu, S., Costanza, R., Troy, A., D'Aagostino, J., Mates W. (2010). Valuing New Jersey's Ecosystem Services and Natural Capital: A Spatially Explicit Benefit Transfer Approach. Environmental Management, 45, 1271-1285. DOI: $10.1007 / \mathrm{s} 00267-010-9483-5$

Kauffman, G., J. (2018). Socioeconomic Value of Delaware Wetlands. University of Delaware Water Resources Center Institute for Public Administration Newark, Del. 19716

Meng, L., Dong, J. (2019). LUCC and Ecosystem Service Value Assessment for Wetlands: A Case Study in Nansi Lake, China. Water, 11, 1597. DOI:10.3390/w11081597

Pandit, A., Ekka, A., Biswas. D. K., Chakraborty L., Bhattachrayya B. K. (2018). Aquatourism in floodplain wetlands as a potential alternative livelihood option for the fisherfolks - A case study of Deepor beel in Assam. Journal of the Inland Fisheries Society of India, 50 (1), 65-70

Roy, M.B., Roy, P. K., Samal, N. R., Mazumder, A. (2012). Socio-economic Valuations of Wetland Based Occupations of Lower Gangetic Basin through Participatory Approach. Environment and Natural Resources Research, 2(4), 30-44. DOI:10.5539/enrr.v2n4p30

Saikia, J. L. (2019). Deepor Beel Wetland: Threats to Ecosystem Services, Their Importance to Dependent Communities and Possible Management Measure. Natural Resources and Conservation, 7(2), 9-24. DOI: 10.13189/nrc.2019.070201

Saikia, P. K., Bhattacharjee, P. C. (1987). A study of the Avifauna of Deepor Beel: A Potential Bird Sanctuary in Assam. Parisah, D. and Prentice, $R$. C. [EDs] 1989. Wetland and Waterfowl Conservation in Asia. Asian Wetland Bureau/ IWRB, Kuala Lumpur.
Saikia, PK. (2005). Qualitative and quantitative study of lower and higher organisms and their functional role in the Deepor Beel Ecosystem. Retrieved 16 April 2012 from, https://www.ndsu.edu/pubweb/ bezbarua/em /Documents/Deepor\%20ReportPrasantaSaikia.pdf

Saikia, P. K., Saikia, M. K. (2011). Biodiversity in Deepor Beel Ramsar site of Assam India, Volume-I Faunal Diversity. USA: Lambert Academic Publishing GMBH \& Co. KG.

Sofia, L. A., Nurlianti, S. (2019). The economic value of the resource utilization of wetlands: comparative study of beje fisheries in North Hulu, Sungai Regency, South Kalimantan, Indonesia. AACL Bioflux, 12(1), 143-150

Stuip, M.A.M., Baker, C.J., Oosterberg, W. (2002). The socio-economics of wetlands. Wetlands International and RIZA, Wageningen. The Netherlands.

Verma, M. (2001). Economic Valuation of Bhoj Wetland for sustainable use. Theme: Wetlands and Biodiversity EERC Working Paper Series: WB-9. World Bank Aided India: Environmental Management Capacity Building Technical Assistance Project. Retrieved 01 March 2012 from, http://iifm.ac.in/wpcontent/uploads/bhojwetlands2001.pdf

Vijayan, V. S., Prasad, S. N., Vijayan, L., Muralidharan, S. (2004). Inland wetlands of India: Conservation Priorities. Sálim Ali Centre for Ornithology and Natural History. Coimbatore.

\section{Acknowledgements}

The authors are grateful to the Gaon Burha (Village Headman) of Keotpara Mr Sarat Das, for his help in conducting a household survey and gathering other secondary data needed for the study. The authors are also thankful to all the respondents for their cooperation and support.

\section{About the Authors}

Dr. Jyotisikha Dutta is the co-investigator of a UGC major research project done in the Department of Women's Studies, Gauhati University. She has been involved in many major and minor research projects conducted in the 
Women's Studies Research Centre, Gauhati University. Her research interests include environmental economics, women's studies, and feminist economics.

Professor Archana Sharma was born in Jorhat but gained her education in Shillong and Guwahati. Professor Sharma, who has now retired as Professor of Economics, Gauhati University served as the Director, Women's
Studies Research Centre, Gauhati University for more than one and half decade and founded the Department of Women's Studies, Gauhati University. Her PhD thesis was titled "Levels of living in Assam: 1955-80" and her research interests include development economics, labour economics, environmental economics, agricultural economics and women's studies. She has guided successfully more than twenty PhD scholars. 